\title{
Analysis of the Dilemma and Path of College Teacher Development in Mainland China
}

\author{
Feng Xiong \\ Southwest Petroleum University, Chengdu, China \\ Email: xiongfengswpu@163.com
}

How to cite this paper: Xiong, F. (2017) Analysis of the Dilemma and Path of College Teacher Development in Mainland China. Open Access Library Journal, 4: e3873.

https://doi.org/10.4236/oalib.1103873

Received: August 4, 2017

Accepted: September 1, 2017

Published: September 4, 2017

Copyright $\odot 2017$ by author and Open Access Library Inc.

This work is licensed under the Creative Commons Attribution International License (CC BY 4.0).

http://creativecommons.org/licenses/by/4.0/

\section{(c) (i) Open Access}

\begin{abstract}
Teacher development (TD) is an important task for colleges and universities in mainland China. By comparing the history and current situation of TD at home and abroad, the study analyzes the dilemmas and causes of TD in mainland China, and explores the paths of TD. Facing these dilemmas that the model of TD is single, development service provided by universities does not match teachers' internal demands, and evaluation system is not perfect, the study tries the following three aspects to explore the paths, which include developing measures at every phase based on college teachers' characteristics, playing the function of TD center and promoting their self-organized development, and establishing and improving the evaluation system of TD and promote coordinated TD.
\end{abstract}

\section{Subject Areas}

Education

\section{Keywords}

Teacher Development, Faculty Professional Development, Dilemma, Path

\section{Introduction}

College teachers have social attributes and play an important role in education system. Teacher development (TD) is the dynamic process of changing the role from student to beginning teacher, then mature teachers, expert teachers and educators. Marx said that the comprehensive development of man is that he is a complete person, in a comprehensive way, possesses his own comprehensive nature. The comprehensive development of college teachers is the Marxist's Comprehensive Development Theory reflected in higher education. In 1991, American Education Association proposed that TD is focused on four purposes, 
which are personal development, professional development, and teaching development and organizational development [1]. Therefore, comprehensive development of college teachers contains personal development, professional development, and teaching development and organizational development.

In 1998, UNESCO noted that a vigorous policy of staff development is an essential element for higher education institutions in World Declaration on Higher Education [2]. Mostly every country around the world has increasingly realized TD's important impact on the quality of higher education. From the early teacher training to nowadays diversified TD, college teachers have developed rapidly. With the internationalization of higher education, the requirements of college teachers in the new period are getting higher and higher. Especially under the construction of World-class Universities and World-class Disciplines, college teacher is the important key. TD belongs to the category of teachers' career development, which has great significance to universities and individuals. On the one hand, it is helpful to implement the concept of quality management and students cultivation in colleges and universities. On the other hand, it can meet the needs of organizational development and teachers' career development. Besides, this study has great significance to effectively guide teachers' career development, promote the comprehensive development of teachers and the construction of teachers' team-building in colleges and universities. At the same time, this research combs the history and current situation of TD at home and abroad, the dilemma and path of it, and summarizes the current situation of TD at home, which can provide a reference for the relevant research.

This paper uses the methods of literature research, comparative research and etc., guiding by the Comprehensive Development Theory, compares the history and current situation of TD at home and abroad at first, and then analyzes the dilemma and causes of TD in China, and explores the paths of TD in colleges and universities. And finally it is the discussion and conclusion.

\section{Comparison: The History and Current Situation of TD at Home and Abroad}

For one thing, TD at abroad started early, and has been highly concerned and has specialized institutions to promote it. For another, TD at home was initially in the stage of introduction, and has developed rapidly in recent years, such as it has been universal, many universities has established TD center. However, TD still has many big problems and it is facing the new dilemma. By comparing the history and current situation of TD at home and abroad, it makes TD clearer and let people fully understand it. In practice, by referring to the experience of TD in foreign universities and combined with the actual situation in China, it's much better to explore the paths of TD.

\subsection{At Abroad}

With the acceleration of globalization, a lot of paths have been put forward in 
foreign universities to promote TD. Universities in Canada usually use the two-level development system. The university set up a special TD institution, such as TD Committee, which is mainly responsible for formulating TD project and evaluation, and TD Center is responsible for implementing TD project and specific training. For its departments, they are also allowed to set up TD Institution, which is similar to TD Center, but only responsible for its own department [3]. The characteristics of TD system in British universities are including that they embody the concept that constructing TD system is important to improve the quality of education, set up a special TD system, and promote the construction of TD system by strengthening scientific research management, as well as have enough funds for constructing TD system and consummating supervision and evaluation [4].

In addition to Canada and the British, TD in the USA has become the object of many countries to learn from. From the late 1960s, colleges and universities in the USA began to pay attention to TD. In 1962, University of Michigan established the first TD institution, which was Learning and Teaching Research Center. Now colleges and universities have generally set up TD center, so that TD has become norm in the States.

In general, TD in foreign countries has experienced germination to mature. TD institution has experienced a considerable period of development, which is from the rise to popularity, has changed from quantitative to qualitative, and promotes the development of higher education effectively.

\subsection{At Home}

Since higher education turning from elite to popular, more and more attention has been paid to cultivating and developing college teachers in mainland China. In recent years, the Government of China advocated actively to establish Teachers' Teaching Development Demonstration Center, introduced a series of policies and measures to guarantee the development of TD. In July 2012, Ministry of Education of the People's Republic of China issued the notice on Initiating the Construction Work of the National Teachers' Teaching Development Demonstration Center. Then in October, it selected 30 National Teachers' Teaching Development Demonstration Center including Xiamen University's during the " $12^{\text {th }}$ Five Year" Period. Various provinces and cities have been responding actively to national policies and accelerating the construction of Teachers' Teaching Development Center. College Teachers' Teaching Development Demonstration Center is a kind of specialized service institution and puts teaching research results to apply for TD, which aims at developing and improving college teachers' teaching level, and whose main functions are spreading ideas of teaching and culture, teaching training and guidance, and researching on teaching and curriculum, as well as teaching evaluation and feedback, and so on [5]. More and more universities recognize that college teachers not only want to develop teaching, but also others, such as academic research. So in fact the early established 
institution is called Teachers' Teaching Development Center, and there are Teacher Development Center (TD center), Teaching Research and Training Center, and Teaching Promotion and Teacher Development Center, etc. now. This study unified use TD center.

On the whole, college teachers have been developing rapidly under the national policies at present. But there are still many problems, such as the development measures are too simple, the communication to other brother universities is not depth enough, and TD center cannot provide full range of personalized development service for college teachers, and the research and practice on $\mathrm{TD}$ is still under the continuous exploration.

\section{Analysis: The Dilemma and Cause of TD}

\subsection{TD Is Confused with Teacher Training, and Development Model Is Single}

TD is often confused with teacher training, but they are very different actually. Teacher training is not autonomous, and development motive is externally, which is an individual development process affected by external environment. However, TD is autonomous, and its development motivation is from internal, which is a self-promotion process based on individual subject consciousness, emphasizing teachers' main position in the development, and it's the essential change from passive to initiative. Teacher training is just one way to promote TD.

Due to mistakenly confused between teacher training and TD, universities mainly provide kinds of training, full-time study, and short-term training and other ways to promote TD, trying to make them develop rapidly by efficient training and learning. But the development model is formalized rather than working as expected. These college teachers have no choice but to participate. What's worse, most universities have not established a complete TD system, without scientific and effective training programs, and TD is lack systematic and standardized. They only carry out training based on experience and make teachers participate in various training activities relaying on administrative orders, ignoring teachers' subjective initiative. This single model seriously hampers the improvement of teachers' level and TD in an all-round way.

\subsection{The Provision of Development Services Doesn't Match Teachers' Internal Demands}

At present, college teachers gradually form the characteristics of younger, and young teachers have become the main force for universities. But most young teachers are hired after graduated, whose experience of teaching is scarce, facing the pressures of scientific research and living. And they are eager to grow rapidly to adapt to the development situation. In addition, with advancing the construction of World First-class Universities and First-class Disciplines, the comprehensive reform of education has been deepened, and the new situation of higher 
education has put forward new challenges and demands to college teachers. So their inner development demands are becoming more and more urgent.

However, most universities are providing insufficient development services by TD center right now, which are mainly in the following three aspects. Firstly, not all staff of TD center has an academic education background, and their research on TD is not deep enough. Secondly, TD center exists not long, and it is still at the phase of experience introduction, whose function has not played out fully yet. Thirdly, TD is operating by the top-to-down mode and guiding by executive's orders, so that it doesn't match teachers' internal development demands.

\subsection{The Evaluation System of TD in Colleges and Universities Is Not Perfect}

With the rapid development of higher education, the original summary evaluation with the main means of rewards and punishment has gradually evolved to developmental evaluation with the purpose of improving and completing. Because of the development of evaluation concept and evaluation mode, it is necessary to keep pace with time when constructing the evaluation system of TD in colleges and universities, which should be multidimensional, comprehensive and developable, and could provide effective guidance. However, it's lack of scientific and reasonable quality evaluation system of TD in colleges and universities in mainland China, and manifests in these areas which are single evaluation system, and lack of flexibility, and do not really play the role of evaluation for development [6].

The evaluation of TD in colleges and universities is end with training program usually, pays little attention to teachers' application in practical work, and doesn't reflect the development of evaluation. In the current evaluation system, there is a tendency that paying more attention to scientific research, and less contempt for teaching, which is focus on the level of academic research, while neglecting other aspects of evaluation. This non-developmental evaluation method and the incomplete evaluation system don't play a solid role in promoting individual development, professional development, and teaching development and organizational development, cannot help teachers improve themselves, but easily lead TD to imbalance.

\section{Exploring: The Paths of TD in Colleges and Universities}

\subsection{Analysis of the Characteristics of TD at Every Phase, and Provide Measures for Different Phases}

The teachers' growth and development have different characteristics at every phase, and development demands are different due to different phases. Learned from other research results, including TD Phase Theory of Burden [7], Teacher Career Development Cycle Model of Fessler [8], and Teacher Career Development Model of Stetty [9], etc., and combined with the actual development of domestic colleges and universities, it can summarize teachers' characteristics at 
the main phases. For example, these teachers at adaptation phase are enjoying as beginning teachers, as well as facing maladjustment of the role changing and the challenges to play multiple roles, who are concerned about adaptation problems. These teachers at adjustment phase initially adapted to the campus atmosphere, are adjusting and consolidating the experience and skills gained, and strive to form personal styles. These teachers at mature phase have a unique educational thinking, and hope to become expert teachers.

When formulating measures for TD, the characteristics of TD at every phase should be under fully consideration and measures must be appropriate for different phases. For example, for these teachers at adaptation phase, universities could carry out learning lecture, teaching salon, and online training about the history of the university, teachers' morality and faith, and teaching methods, as well as skills training, so that teachers will understand its development process, academic characteristics, and campus culture well. And they could master basic teaching skills and methods, and change the role as soon as possible and integrate into the university atmosphere. For these teachers at adjustment phase, universities should encourage them to participate in team building, laboratory construction, and teaching reform and various competitions at all levels, and learn from and communicate with each other to enhance all aspects of capacity. For these teachers at mature phase, universities should take effective measures to promote their research results into teaching practice, and strive to achieve outstanding results in the quality of higher education as well as teaching reform project.

\subsection{Play the Function of TD Center, and Promote Teachers Self-Organization Development}

TD center aims at promoting college teachers' business level and teaching ability. And its main work consists of training, consultation, and teaching research and evaluation. Training is for all teachers in the university and mostly focus on young teachers to update the educational philosophy and improve business level. Consultation helps teachers analyze the problems encountered in the development process to meet the demands of teachers personalized development. Teaching research makes teachers focus on teaching initiatively, and improves teaching strategies and effectiveness by advanced teaching ideas. Evaluation is due to strengthen the assessment and testing teachers' business level and teaching ability, and evaluation promotes development.

University is an important field of TD, and TD center should provide strong support for teachers. TD center should combine the dual nature of administrative institution and academic institution, and integrate organically these two into a specialized institution which is responsible for teacher professional development [10]. On the one hand, TD center should strengthen the theoretical research on TD, play the value of its academic institution, and make research guide practice, and abandon the single training mode. Meanwhile, it should be 
combined with training seminar, expert advice, and teaching salon and resource sharing and other ways to enrich TD models and meet teachers' inherent demands. On the other hand, TD center should play the value of its administrative institution, formulating policies and measures to stimulate teachers' intrinsic motivation, and formatting self-organized development model drive by teachers' intrinsic. Regarding teachers' inner demands as starting point, TD center provides actively college teachers with diversified and free development field, and exerts teachers' subjectivity and initiative. Through teacher-driven self-organization development and the support from TD center, it will effectively meet teachers' demands.

\subsection{Establish and Improve the Evaluation System of TD in Colleges and Universities, and Promote Teachers Coordinated Development}

Evaluation is one of the effective ways to promote teaching with many functions such as diagnosis, encouragement and help. Effective evaluation can be a good opportunity to drive teachers to study on teaching and promote teaching level. However, improper evaluation may become the shackles of restricting TD [11]. Therefore, when constructing evaluation system of TD in colleges and universities, it must integrate four aspects, which are personal development, professional development, and teaching development and organizational development, with the purpose of promoting TD comprehensively. So the structure of evaluation system is scientific and rational, and the content is comprehensive and effective. For a university, a functional department cannot construct TD evaluation system completely, which requires other relevant departments to work together, such as Personnel Office, Research Department, and The Office of Academic Affairs.

TD is a four-in-one structure with personal development, professional development, and teaching development and organizational development, which are indispensable. Only these four aspects develop collaboratively, can promote teachers to develop comprehensively and coordinated sustainably. In this process, it should pay attention to the following aspects. First, organizational development is in harmony with personal development. Teachers' personal development should be combined with the development of university, and the university should create a harmonious, democratic and free teaching atmosphere and provide organizational security for TD. Second, teaching development is in harmony with professional development. The university should support teachers in carrying out scientific and technological innovation activities, encourage teachers to integrate the latest research results into teaching, and play the role of scientific research to promote teaching. Third, internal demands are in harmony with external incentives. Beginning with teachers' internal demands of development and the external incentives for improving TD, the university should establish a sound and effective system to promote TD. Fourth, theoretical learning is in harmony with practice training. Teachers should not only have the theoretical knowledge of learning and accumulation, but also under the guidance of theoretical 
knowledge for practical training to promote TD comprehensively.

\section{Discussion and Conclusion}

TD affects the quality of higher education, and all colleges and universities must attach great importance to it. The problems faced by TD in colleges and universities are not only difficult problems, but also important opportunities. While TD center is becoming more and more popular in various colleges and universities, central role has become increasingly prominent. Promoting TD is a new exploration by TD center in mainland China. Facing the dilemma that TD is confused with teacher training, development model is single, and the provision of development services doesn't match teachers' internal demands, and the evaluation system of TD in colleges and universities is not perfect, the study provides the following three paths:

1) Analyze the Characteristics of TD at Every Phase, and Provide Measures for Different Phases.

2) Play the Function of TD Center, and Promote Teachers Self-organization Development.

3) Establish and Improve the Evaluation System of TD in Colleges and Universities, and Promote Teachers Coordinated Development.

TD consists of personal development, professional development, and teaching development and organizational development. These four aspects have profound connotations, such as teaching development, it always implement the student-centered concept, concerns about the teaching effect and learning effect, and it is not a simple thing. These four aspects are interrelated and each two of $\mathrm{TD}$ are closely related, and the focus and difficulty lies in the coordination of the four aspects. So how to effectively promote college teachers' personal development, professional development, and teaching development and organizational development coordinated and sustainably is an important direction to study on for colleges and universities in the future.

\section{Acknowledgements}

This work is supported by Teacher Education Research Center of Sichuan Province (No. TER2015-009).

\section{References}

[1] Lin, J. (2006) The Definition and Strategies of Faculty's Professional Development. University Education Science, 56-58.

[2] UNESCO (1998) World Declaration on Higher Education. http://www.unesco.org/education/educprog/wche/declaration_eng.htm

[3] Li, S.H. and Guo, W. (2012) Teacher Development in the Context of Internationalization: Experience from Canada. Chinese Higher Education, 60-62.

[4] Hu, G. (2012) The Formation, Features and Enlightenments of University Teacher Development System in UK. Journal of Jishou University. Social Science Edition, 1, 162-165. 
[5] Chen, Z.Y. (2013) On the Roles of the Teaching Development Center of University Teachers. Higher Engineering Education Research, 6, 92.

[6] Zhu, F., Li, R. and Xu, Y.Y. (2013) Research on the Teachers' Development in Colleges and Universities of Chinese Mainland. Hebei North University: Social Sciences, 83-88.

[7] Newman, K.K., Burden, P.R. and Applegate, J.H. (1980) Helping Teachers Examine Their Long-Range Development. The Teacher Educator, 15, 7-14. https://doi.org/10.1080/08878738009554738

[8] Fessler, R. (1985) A Model for Teacher Professional Growth and Development. In: Burke, P.J. and Heideman, R.G., Eds., Career-Long Teacher Education, IL Charles C. Thomas, 181-193.

[9] Stetty, B. (1990) Teacher Career Development Pattern. Teacher Development, 12, 29.

[10] Bie, D.R. and Li, J.X. (2014) The Characteristics and Functions of Faculty Development Center. Fudan Education Forum, 12, 41-47.

[11] Mao, Y.H. (2007) Enhancing Teacher's Development through Power of Teamwork. Development and Evaluation of Higher Education, 23, 91-98.

Submit or recommend next manuscript to OALib Journal and we will provide best service for you:

- Publication frequency: Monthly

- 9 subject areas of science, technology and medicine

- Fair and rigorous peer-review system

- Fast publication process

- Article promotion in various social networking sites (LinkedIn, Facebook, Twitter, etc.)

- Maximum dissemination of your research work

Submit Your Paper Online: Click Here to Submit

Or Contact service@oalib.com 